\title{
PENDAMPINGAN BELAJAR SISWA MELALUI KEGIATAN BIMBINGAN BELAJAR DI DESA SONGAN DALAM MEMUTUS LAJU PENYEBARAN COVID 19
}

\author{
1)I Nyoman Sudirman, ${ }^{2)}$ N. W. S. Darmayanti, ${ }^{2)}$ Putu Beny Pradnyana, \\ 3)Pande Agus Adiwijaya
}

\author{
1)Fakultas IImu Pendidikan Prodi Bahasa \& Sastra Indonesia ITP Markandeya Bali, Bangli, Bali, Indonesia \\ 2)Fakultas IImu Pendidikan Prodi Pendidikan Guru Sekolah Dasar ITP Markandeya Bali, Bangli, Bali, Indonesia \\ ${ }^{3)}$ Fakultas IImu Pendidikan Prodi Pendidikan Bahasa Inggris ITP Markandeya Bali, Bangli, Bali, Indonesia \\ Corresponding author: I Nyoman Sudirman \\ Email: putrateacher@gmail.com
}

Diterima 30 November 2021, Direvisi 02 Desember 2021, Disetujui 02 Desember 2021

\begin{abstract}
ABSTRAK
Penyebaran virus covid 19 yang melanda dunia harus mengubah paradigma pendidikan yang sebelumnya di laksanakan secara tatap muka di sekolah berubah harus belajar secara mandiri dirumah. Tujuan belajar dirumah adalah untuk membatasi laju dan mencegah perkembangan virus covid 19 . Kegiatan proses belajar di rumah memunculkan berbagai persoalan bagi anak-anak maupun orang tua, beberapa pelajaran yang harus diselesaikan oleh anak-anak tidak bisa dipahami secara baik. Harapananak-anak bisa dibantu belajar oleh orang tuanya masing-masing juga mengalami kendala akibat kurang pahamanya orang tua terhadap materi pembelajaran yang harus diselesaikan oleh anak-anak selama belajar di rumah. Masalah yang dihadapi oleh anak-anak maupun orang tua tim pecahkan dengan memberikan solusi melakukan pendampingan belajar dirumah. Tujuan dilaksanakan pendampingan belajar dirumah ialah untuk membantu anak-anak memahami materi serta membantu menyelesaikan tugas-tugas yang diberikan oleh gurunya untuk diselesaikan dirumah selama pembelajaran di lakukan dirumah. Pendampingan belajar dirumah disusun dengan metode secara langsung dilakukan ke rumah-rumah anak-anak yang berada di wilayah desa songan untuk memberiakan bantuan pembelajaran tambahan pada materi-materi yang tidak bisa di pahami oleh anak-anak. Pegabdian masyarakat berupa pendampingan belajar di rumah telah memberikan kontribusi yang positif kepada anak-anak yang berada di wilayah desa songan. Anak-anak maupun orang tuanya yang didampingi belajar oleh tim pegabdian sangat senang dengan ada kegiatan seperti ini serta merasa terbantu untuk memahami materi yang tidak bisa di pahami secara mandiri dirumah.
\end{abstract}

Kata Kunci: sekolah dasar; pendampingan belajar;covid 19

\begin{abstract}
Covid-19 pandemic has drastically changed the education paradigm from face-to-face interaction at school to be learning independently at home. Learning at home is aimed at restricting the spread and rate of the Covid-19 virus. Learning at home has caused various problems for the students and parents. Some subjects could not be understood well by the students. The hope of the students being assisted by their parents could not also be realized since the parents did not understand the learning materials that should be learned by the students at home. This problem was overcome by the team with learning assistance at home. The goal of learning assistance at home was assisting the students to understand learning materials and finishing the assignments from the teachers during learning from home. Learning assistance at home was conducted with a direct method to be conducted at home in Songan Village to support additional learning sessions for the subjects that are not understood yet. This community service in form of learning assistance has positively contributed to the students in Songan Village. Both the students and parents were happy to get this learning assistance since they were helped to understand the learning materials from learning at home independently.
\end{abstract}

Keywords: elementary school; learning assistance; covid-19

\section{PENDAHULUAN}

Adanya Penyebaran virus covid 19 di dunia yang hampir melanda semua negara didunia. Imbas dari penyebaran virus covid 19 membuat negara di dunia harus membuat kebijakan bagi sebuah negara untuk memutus laju penyebaran virus covid 19. Salah satu kebijakan yang yang diambil oleh negara Indonesia terkait untuk memutus laju penyebaran virus covid 19 adalah membuat kebijakan untuk meliburkan lembaga institusi yang bergerak dalam pendidikan. 
Kebijakan tersebut mengharuskan semua lembaga pendidikan agar memberikan pembelajaran dirumah dengan mekanisme secara online di seluruh wilayah Indonesia. Kebijakan ini diyakini sebagai salah jalan hal yang bisa mengurangi laju penyebaran virus covid 19 di Indonesia (Wahyu, 2020)

Menindaklanjuti tersebut pemerintah provinsi Bali juga melakukan kebijakan pemerintah pusat dengan memberlakukan kebijakan belajar di rumah yang dilakukan secara online dirumah. Pelaksanaan kebijakan belajar dirumah secara online seharusnya harus didukung dengan media yang memmadai yang bisa menjamin proses pelaksanaan pembelajaran dirumah secara online. Namun kenyataanya daya dukung media tersebut tidak bisa di miliki oleh semua orang. Hal ini masih bisa kita lihat ada beberap anak didik tidak memiliki hp dan tidak didukung dengan koneksi internet yang memadai sehingga proses pembelajaran dirumah dengan mekanisme yang secara online, rendahnya daya dukung ini menyebabakan anak-anak tidak bisa mengikuli proses pembelajaran secara maksimal yang di berikan oleh masing-masing gurunya.

Proses pembelajaran yang tidak bisa diikuti oleh anak-anak secara maksimal menyebabkan sebagain mata pelajaran tidak dimengerti oleh anak-anak dengan baik. Alasan tidak adanya daya dukung internet dan daya dukung yang lain pada akhirnya guru hanya akan memberikan tugas-tugas kepada anak didik, sebagain ada anak-anak didik tidak mengerti dengan tugas yang diberikan oleh gurunya. Ketidak mengertian ini memunculkan sebuah persoalan bagaimana cara bisa kita lakukan untuk bisa memecahkan masalah tersebut. Salah satu solusinya bisa dilakukan dengan belajar dengan sistem pendambingan belajar di rumah selama adanya wabah virus covid 19( Rizqon 2020).

Bertalian dengan persoalan tersebut maka, kami melakukan pendampilangan belajar dirumah selama penyebaran virus covid 19 di wilayah desa songan untuk membantu anakanak belajar di rumah. Tujuan kegiatan ini adalah untuk membantu anak-anak menyelesaikan tugas-tugas yang di berikan oleh gurunya untuk di pelajari dirumah serta membantu menyelesaikan materi yang dianggap sulit oleh anak-anak tersebut. Pendampingan belajar yang dilakukan di desa songan melibatkan beberapa mahasiswa yang berada diprogram pendidikan guru sekolah dasar dan program pendidikan Bahasa inggris. Kegiatan pendampingan ini kita lakukan dari bulai mei 2021 sampai dengan bulan juli yang di lakukan kurnag lebih selama 2 bulan.

\section{METODE}

Kegiatan pendampingan ini dilaksanakan selama 2 bulan, yaitu bulan Mei sampai Juli. Kegiatan dilaksanakan seminggu sekali yang disesuaikan dengan keadaan siswa. Adapun tempat pelaksanaan kegiatan adalah bertempat desa songan Kecamatan Kintamani Kabupaten Bangli. Kegiatan ini diikuti oleh 10 orang anakanak SD.

Proses pelaksanaan pengabdian kepada masyarakat Fakultas IImu Pendidikan ITP Markandeya Bali ini dilaksanakan dengan menggunakan model pendampingan belajar secara langsung kerumah anak bersangkutan dengan melibatkan beberapa mahasiswa fakultas ilmu pendidikan prodi PGSD dan Pendidikan Bahasa Inggris serta dosen untuk memberi pendampingan pembelajaran di rumah semasa diterapkan pembelajaran di rumah oleh pihak sekolah. Kegiatan ini dilakukan di wilayah di desa songan Kecamatan Kintamani Kabupaten Bangli. Adapun mekanismenya pengabdiannya dapat dilihat pada Gambar 1.

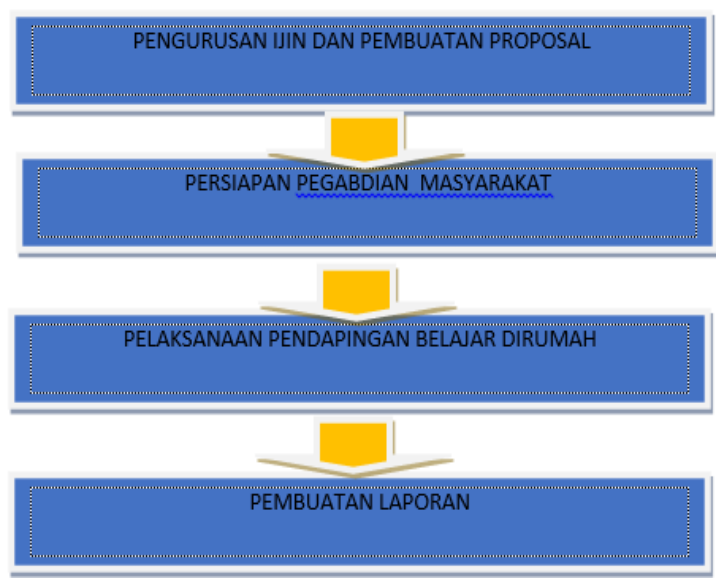

Gambar 1. Mekanisme kegiatan pengabdian

\section{HASIL DAN PEMBAHASAN}

Proses pendampingan pembelajaran yang dilaksanakan di desa songan guna membantu anak-anak belajar untuk mendapat pembelajaran tambahan. Dalam proses kegiatan ini tetap menerapkan protokol kesehatan untuk mencegah laju penyebaran virus covid 19. Pada kegiatan ini murid di bantu untuk menyelesaikan tugas-tugas rumah yang diberikan oleh guru. Adapun pembelajaran yang diberikan ialah 5 bidang mata pelajaran. Selain itu juga diberikan pendampingan berupa pembelajaran bahasa inggris dasar bagi anakanak SD. Pada kegiatan ini mahasiswa dan dosen memberikan materi untuk pendampingan belajar. Kegiatan Pelaksanaan kegiatan ini ikuti oleh anak-anak kelas 1 sampai kelas 6 SD. 
Kegiatan ini di lakukan seminggu sekali yang dilakukan selama 2 bulan oleh tim pengabdian. Proses pelaksanaan dilakukan pada siang hari hari sampai sore hari. Anak-anak yang terlibat dalam kegiatan ini adalah (1) Ni Kadek Kartini (kelas 1); (2) Ni Kadek Mira (kelas 3); (3) Ni Wayan Karina (kelas 3); (4) Ni Komang Sukerni (kelas 4): (5) Ni Wayan Rani Junita (kelas 5); (6) Puspa Dei dinawati (kelas 4); (7) Ni Putu Pratami (kelas 5); (8) Komang Widya Pratiwi (kelas 5); (9) Ketut Abelia Fatmawati (kelas 6); (10) Komang Metriyani (kelas 6). Adapun proses pendampingan dapat dilihat pada Gambar 2 berikut.

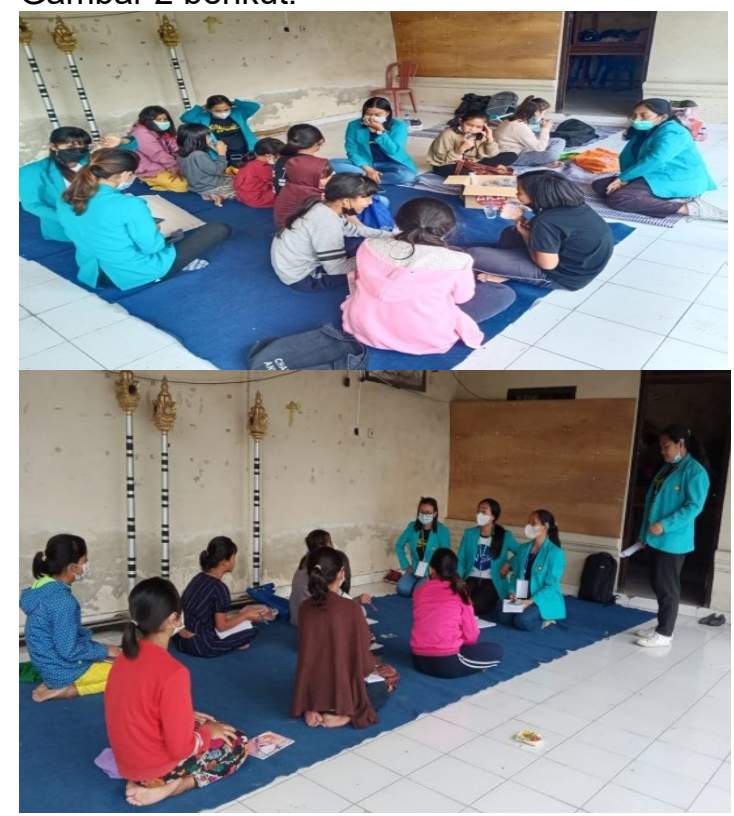

Gambar 2. Proses Pendampingan Belajar

Program pendampingan pembelajaran di mulai dari Mei sampai Juli 2021 yang dilaksanakan diwilayah desa Songan yang ada di kabupaten Bangli dengan melibatkan beberapa mahasiswa dari prodi pendidikan guru sekolah dasar dan pendidikan Bahasa Inggris. Kegiatan pendampingan belajar yang dilakukan selama 120 menit setiap kali pertemuan. Kegiatan pendampingan belajar ini telah memberikan kontribusi bagi anak-anak SD selama pandemi dalam hal belajar di rumah. Dengan adanya kegiatan ini, anak-anak menjadi tambah semangat dan termotivasi untuk belajar dan mengerjakan tugas rumah selama pandemi. Pelaksanaan kegiatan ini membantu anak-anak SD untuk belajar serta membantu ornag tua siswa untuk mendampingi anak-anaknya dalam mengerjakan tugas. Kegiatan ini dapat berjalan lancar tidak terlepas dari dukungan orang tua siswa dan kepala desa Songan yang sangat baik menerima kami untuk mendampingi kegiatan belajar untuk siswa. Proses kegiatan ini juga membantu pemerintah dalam mencerdaskan kehidupan anak-anak. Proses pembelajaran yang dilakukan secara daring telah membuat kesulitan bagi siswa untuk mengamahami materi sebagaimana penelitian yang di lakukan Mufarikhah (2020) menemukan bahwa siswa masih kesulitan untuk belajar kelas jauh di masa covid 19, sehingga kegiatan pendampingan belajar sangat di perlukan olah anak-anak untuk bisa membantu mereka memahami materi pembelajaran yang di berikan olah pihak sekolah. Pendampingan belajar seperti ini melalui pengabdian sangat membantu anak-anak untuk memahami materi yang akan di pelajari oleh mereka. Sejalan itu Pradnyana (2020) menyatakan pegabdian pendampingan belajar dirumah sangat baik di lakukanan untuk mempermudah anak-anak memahami materi pembelajaran. Selanjutnya handayani (2020) mengatakan bahwa pendampingan belajar di rumah di masa pandemic covid 19 memberikan nilai positif bagi anak-anak untuk memahami materi pembelajaran. Bertalian dengan hal tersebut bahwa pendapingan belajar dirumah yang di lakukan secara ofline lebih membuat anananak bersemangat belajar (Asri, 2020).

\section{SIMPULAN DAN SARAN}

Berdasarkan hasil pembahasan pengabdian di atas, dapat disimpulkan bahwa pendampingan belajar dirumah ini telah membantu anak-anak lebih memahami materi pembelajaran serta sangat menyenangkan bagi anak-anak karena merasa terbantu dalam menyelesaikan tugastugas yang di bebankan oleh gurunya di sekolah. Hendaknya kegiatan seperti ini bisa berlanjut untuk membantu siswa yang mengalami kesulitan dalam mengerjakan tugas sekolah.

\section{UCAPAN TERIMAKASIH}

Ucapan terimakasih yang sebesar-besarnya bagi semua pihak yang membantu dalam kegiatan pegabdian pendampingan belajar dirumah sehingga pelaksanaannya dapat berjalan dengan lancar.

\section{DAFTAR RUJUKAN}

Asri dkk, (2020) Pendampingan Belajar dari Rumah Untuk Anak Sekolah di Masa Pandemi Covid-19 Kecamatan Purwanegara, Kabupaten Banjarnegara,https://kkn.unnes.ac.id/la pkknunnes/32004 33040420106 De sa\%20 20201004 194028.pdf, Di Akses Pada Tanggal 5 Desember 2020

Handayani dkk, (2020), Pendampingan Belajar Di rumah Bagi Siswa Sekolah Dasar Terdampak

Covid9,Tersediapada:https://jurnal.unti dar.ac.id/index.php/abdipraja/article/vi 
ew/3209/pdf, diakses pada tanggal 3

Desember 2020

Mufarikhah Umar, (2020) Studi Kepustakaan

Tentang Dampak Wabah Covid-19

Terhadap Kegiatan Belajar Mengajar

Pada Siswa Sekolah

Dasar(Sd), TersediaPada:Https://Jurnal

mahasisw.Unesa.Ac.Id/Index.Php/Jurn

alBkUnesa/Article/View/34440, Di

Akses Pada Tanggal 5 Mei 2020

Pradnyana dkk, (2020) Pendampingan

Kegiatan Belajar Di Rumah Secara

Privat Di Masa Pandemi Covid-19 di

lingkungan Kabupaten Bangli Bagian

Utaratersediapada:http://journal.umma

t.ac.id/index.php/ipmb/article/view/338

3/2086, diakses pada Tanggal 4

Desmber 2020

Rizqon Halal Syah Aji, (2020). Dampak Covid19

padaPendidikandilndonesia:Sekolah,K

eterampilan, dan Proses

Pembelajaran, tersedia pada:

https://core.ac.uk/download/pdf/32599

2698.pdf, diakses pada tanggal 3 Mei 2020

Wahyu Aji Fatma Dewi (2020), Dampak Covid19 Terhadap Implementasi Pembelajaran Daring Di

SekolahDasar,Tersediapada:https://co re.ac.uk/reader/322536540, diakses pada tanggal 29 Mei 2020 